\author{
Самофратова B.A. \\ кандидат економічних наук, доцент \\ E-mail: vica_samofatova@mail.ru \\ Демчук C.I. \\ магістрант \\ кафедра економіки промисловості \\ Одеська національна академія харчових технологій \\ вул. Канатна, 112, м. Одеса, Україна, 65039 \\ E-mail: svetlana93@i.ua
}

\title{
СУЧАСНИЙ СТАН ТА НАПРЯМИ РОЗВИТКУ РИБНОГО ГОСПОДАРСТВА У ВНУТРІШНІХ ВОДОЙМАХ УКРАЇНИ
}

Проаналізовано тенденції розвитку рибного господарства України, визначено проблемні аспекти забезпечення населення України вітчизняною рибою та продукцією її переробки. В статті досліджено складові відновлення функціонування внутрішніх водойм України, виділені основні проблеми та перспективи їх вирішення у сучасних умовах. технології.

Ключові слова: рибне господарство, прісноводні водоймища, інвестування, інноваційні

Постановка проблеми та ії зв'язок з важливими науковими і практичними завданнями. Рибне господарство - галузь народного господарства, до якої належить добування, переробка, відтворення і збільшення запасів риби та інших водних організмів у природних і штучних водоймах. Дає цінні харчові, кормові, лікарські й технічні продукти. Серед річок України основне рибогосподарське значення мають Дніпро (серед його притоків - головні Прип'ять і Десна), нижній Дунай, меншою мірою Дністер, Південний Буг і Сіверський Донець. Рибне господарство України відіграє значну роль у забезпеченні населення продовольством, а галузей національної економіки - сировиною, а також у відтворенні природних ресурсів та підвищенні зайнятості населення.

Аналіз останніх публікацій 3 проблеми. Проблема економічного розвитку рибного господарства України розглядалася в працях вітчизняних науковців - С.І. Алимова, П.П. Борщевського, М.С. Стасишена, М.А. Хвесика, Н.М. Яркіної та ін. Вона також знайшла відображення у відповідних Законах України, Державних програмах та законодавчих актах, а саме - «Про рибу, інші водні живі ресурси та харчову продукцію 3 них» [1]; «Про аквакультуру» [2]; «Про рибне господарство, промислове рибальство та охорону водних біоресурсів» [3]; «Про Концепцію розвитку рибного господарства України» тощо. Проте, не дивлячись на те, що проблеми розвитку рибного господарства $\epsilon$ предметом багатьох наукових досліджень, багато питань залишаються невирішеними. Зокрема, проблеми адаптації рибництва та рибопереробної галузі до сьогоднішніх умов господарювання, через різке зростання цін на імпортну рибу для споживачів та як промислову сировину.

Формулювання мети дослідження. Мета дослідження полягає в аналітичній оцінці сучасного стану та напрямів розвитку рибного господарства у внутрішніх водоймах України.

Виклад основних результатів та їх обгрунтування. Рибне господарство має суттєве значення в організації раціонального харчування населення, оскільки рибні продукти є одним із джерел білків і жирів тваринного походження. Річна норма споживання рибних продуктів, розроблена Інститутом харчування Академії медичних наук України, складає 20 кг на душу населення, 3 них 5-6 кг риби прісноводних водойм [6]. В 1991 році Україна займала лідируючі позиції по вилову риби. Тоді українці споживали 24 кг риби в рік, а сьогодні в споживчому кошику української риби лише 2 кг, останнє - імпорт. 3 втратою Криму, імпорт риби зріс до $90 \%$.

Нині рибництво переживає проблематичні часи, які склалися через фінансові труднощі в державі, а саме: порушення господарських зв'язків, погіршення екологічного стану внутрішніх водойм, недостатній обсяг робіт по відтворенню рибних запасів. Це значно впливає на зменшення обсягів вирощування і вилову товарної риби у внутрішніх водоймах .

Крім того, $з$ широкого кола першочергових завдань, що стримують подальший розвиток рибного господарства, на нашу думку, можна виокремити наступні:

- стан відтворення та охорони водних біоресурсів;

- відновлення функціонування наявних внутрішніх водойм країни для їх ефективного використання за призначенням;

- державне регулювання та підтримка галузі.

Також негативний вплив за стан рибогосподарського комплексу спричинила анексія Криму, адже через це Україна зазнала втрат рибного вилову. Зокрема, після анексії Криму, Україна втратила близько 2/3 всього вилову риби. Для прикладу, у 2013 
році Україна виловила 216 тис. тонн риби. 3 них 82 тис. тонн було виловлено в Азово-Чорноморському басейні, 3 яких 52 тис. тонн виловили кримські рибалки, тобто, більше 65\% всього вилову регіону. Також, не слід забувати, що флотом України, що знаходиться в Севастополі, було виловлено 98 тис. тонн. Якщо підсумувати ці цифри, то ми маємо у підсумку 150 тис. тонн, тобто, 2/3 всього вилову припадало на АР Крим [9]. Для підтримання належних обсягів вилову риби у внутрішніх водоймах України, пропонується збільшити іiі вирощування на материковій частині
України. Суттєве підвищення обсягів вирощування ставкової риби можна забезпечити за рахунок надання для рибогосподарських цілей в оренду водних об'єктів місцевого та загальнодержавного значення. Водночас, це може збільшити навантаження на внутрішні водоймища країни та погіршити екологічний стан річок.

Стан рибного господарства України у 2014 році (без урахування тимчасово окупованої території Автономної Республіки Крим і м. Севастополя) наведено у табл. 1 [8].

Стан рибного господарства України у 2014 році

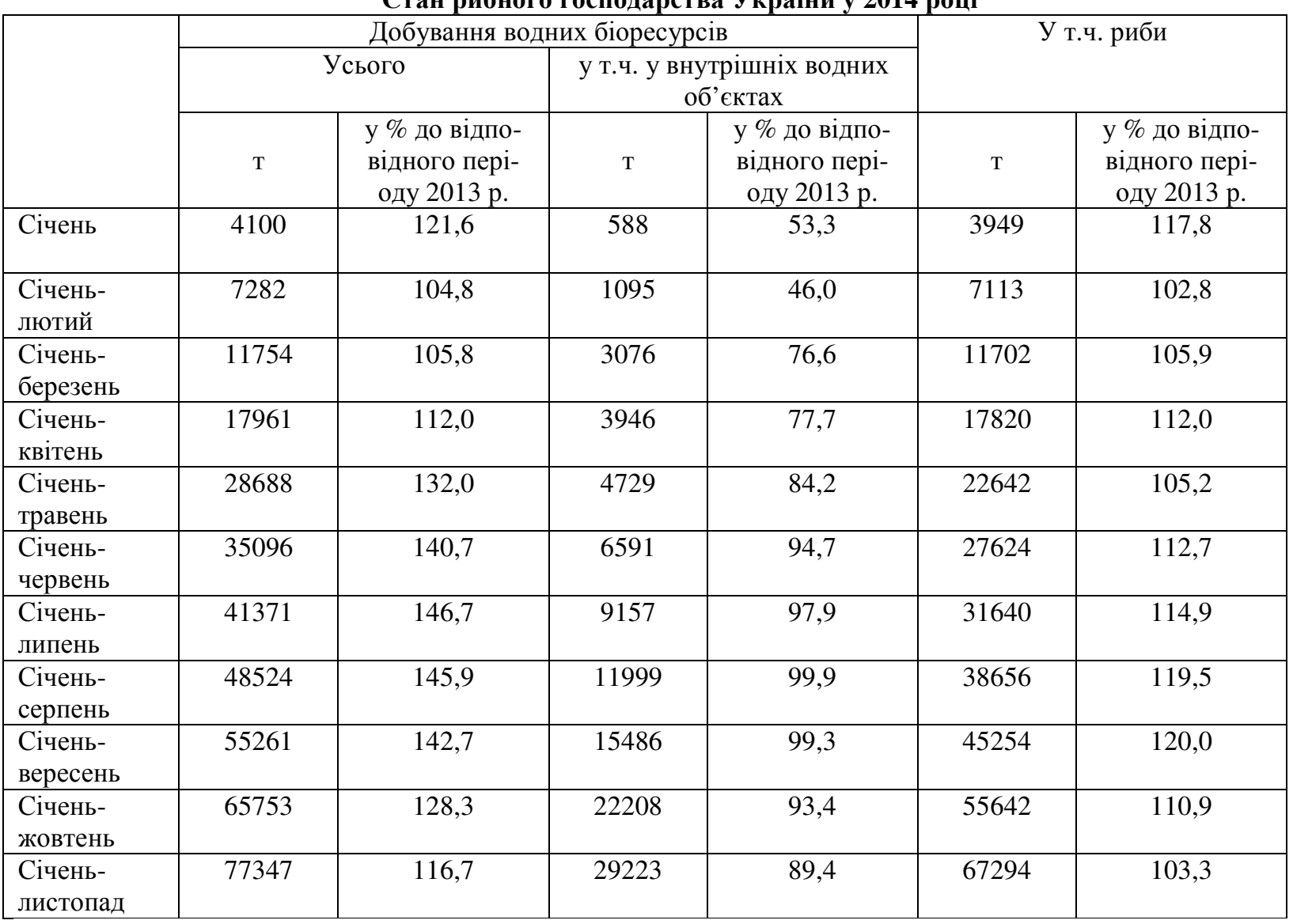

3 наведених у таблиці 1 даних випливає, що найбільше зростання вилову риби спостерігалося у період січень-вересень досліджуваного року; у порівнянні з попереднім періодом воно становить 120,0\%. Під кінець 2014 року видно значний спад цього показника до рівня 103,3\%. Орієнтовно, такі ж показники спостерігалися і на початок року.

Дані таблиці 1 також свідчать, що у січнілистопаді 2014 р. підприємствами та фізичними особами-підприємцями, що здійснюють рибогосподарську діяльність було виловлено та добуто 67294 т риби та інших водних живих ресурсів, що в розрахунку на 1 мешканця становить менше ніж 1,5 кг. Тому, близько 90\% риби, що споживають українці, імпортується з-за кордону. За даними Держкомстату, в порівнянні з відповідним періодом 2013 року, вилов риби у 2014 р. зріс на 3,3\%, а обсяг добування інших водних живих ресурсів становив 77347 т, що на 16,7\% більше, ніж минулого року.

Рибне господарство за регіонами у січнілистопаді 2014 року (без урахування АР Крим і м. Севастополя) представлено у табл. 2 [8]. 
ISSN 2312-847X ЕКОНОМІКА ХАРЧОВОЇ ПРОМИСЛОВОСТІ № 2(26) 2015

Таблиця 2

Рибне господарство за регіонами у січні-листопаді 2014 р.

\begin{tabular}{|c|c|c|c|c|c|c|}
\hline & \multicolumn{4}{|c|}{ Добування водних біоресурсів } & \multirow{2}{*}{\multicolumn{2}{|c|}{ У т.ч. риби }} \\
\hline & \multicolumn{2}{|r|}{ Усього } & \multicolumn{2}{|c|}{$\begin{array}{c}\text { В т.ч. у внутрішніх вод- } \\
\text { них об'єктах }\end{array}$} & & \\
\hline & $\mathrm{T}$ & $\begin{array}{l}\text { у \% до відпо- } \\
\text { відного пері- } \\
\text { оду } 2013 \text { р. }\end{array}$ & $\mathrm{T}$ & $\begin{array}{l}\text { У \% до відпо- } \\
\text { відного пері- } \\
\text { оду } 2013 \text { р. }\end{array}$ & $\mathrm{T}$ & $\begin{array}{l}\text { у \% до відпо- } \\
\text { відного пері- } \\
\text { оду } 2013 \text { р. }\end{array}$ \\
\hline Украӥна & 77347 & 116,7 & 29223 & 89,4 & 67294 & 103,3 \\
\hline \multicolumn{7}{|l|}{ Області } \\
\hline Вінницька & 1608 & 95,0 & 1608 & 95,0 & 1608 & 95,0 \\
\hline Волинська & 488 & 96,8 & 488 & 96,8 & 488 & 96,8 \\
\hline Дніпропетровська & 1580 & 87,7 & 1580 & 89,8 & 1579 & 87,7 \\
\hline Донецька & 2914 & 57,4 & 2014 & 68,0 & 2914 & 57,4 \\
\hline Житомирська & 390 & 73,3 & 390 & 73,3 & 390 & 73,3 \\
\hline Закарпатська & 302 & 76,4 & 302 & 76,4 & 302 & 76,4 \\
\hline Запорізька & 15271 & 94,9 & 1015 & 68,9 & 15170 & 95,3 \\
\hline Івано-Франківська & 580 & 96,1 & 580 & 96,1 & 580 & 96,1 \\
\hline Київська & 1872 & 124,6 & 1541 & 102,6 & 1871 & 124,5 \\
\hline Кіровоградська & 906 & 123,5 & 906 & 123,5 & 906 & 123,5 \\
\hline Львівська & 563 & 72,6 & 563 & 72,6 & 563 & 72,6 \\
\hline Миколаївська & 12120 & 556,7 & 1436 & 73,9 & 2911 & 134,4 \\
\hline Одеська & 7578 & 91,8 & 4405 & 100,6 & 6966 & 94,3 \\
\hline Полтавська & 1234 & 127,9 & 1234 & 127,9 & 1234 & 127,9 \\
\hline Рівненська & 545 & 67,2 & 545 & 67,2 & 545 & 67,2 \\
\hline Сумська & 1087 & 72,6 & 1087 & 72,6 & 1087 & 72,6 \\
\hline Тернопільська & 152 & 100,1 & 152 & 100,1 & 152 & 100,1 \\
\hline Харківська & 936 & 96,7 & 936 & 96,7 & 936 & 96,7 \\
\hline Херсонська & 2047 & 65,1 & 1644 & 75,1 & 1935 & 63,6 \\
\hline Хмельницька & 147 & 63,1 & 147 & 63,1 & 147 & 63,1 \\
\hline Черкаська & 4913 & 108,1 & 4913 & 108,1 & 4913 & 108,1 \\
\hline Чернівецька & 564 & 94,2 & 564 & 94,2 & 564 & 94,2 \\
\hline Чернігівська & 975 & 104,2 & 975 & 104,2 & 975 & 104,2 \\
\hline м. Київ & 18484 & 155,9 & 107 & 169,7 & 18467 & 155,8 \\
\hline
\end{tabular}

3 таблиці 2 видно, що за 2014 рік вилов риби на території України складав 67294 т, у відсотковому значенні цей показник більше за 2013 рік лише на $3,3 \%$. При чому найбільше всього риби виловлюється у м. Київ - 18467 т, значення якого у 2014 році в порівнянні з 2013 роком зросло на 55,8\%. У Запорізькій області вилов складав 15170 т, але у порівнянні з попереднім роком спостерігаємо скорочення цього показника на 4,70\%. Третє місце по вилову риби посідає Одеська область - 6966 т, де також спостерігається тенденція зниження на 5,7\%.

3 цього випливає висновок, що ринок рибної промисловості України не забезпечується за рахунок власних ресурсів. Тому Україна постійно імпортує продукцію у партнерів-нерезидентів.

Розглянувши низку проблем рибопереробного комплексу України, слід відзначити, що збільшення обсягів вилову риби можливе у Дніпровських водосховищах, зокрема, за рахунок поліпшення умов природного відтворення риб шляхом проведення загальної меліорації мілководдя та збільшення обсягів вселення рибопосадкового матеріалу цінних видів риб в Кременчуцьке та Дніпродзержинське водосховища. Слід зауважити, що доцільно продовжувати роботу, спрямовану на переорієнтацію господарств внутрішніх водойм на широке впровадження ресурсозберігаючих технологій з переходом підприємств на прогресивні технології вирощування товарної риби.

Специфічні особливості галузі рибної промисловості вимагають здійснення невідкладної державної підтримки щодо створення сприятливих умов у сфері кредитування та залучення інвестицій. Результати аналізу економічної ситуації України у галузі рибної промисловості, що склалася в рибному господарстві внутрішніх водоймищ, а також тенденції можливих змін свідчать, що в разі відсутності державної підтримки галузі не будуть подолані негативні закономірності в її розвитку.

Для забезпечення розвитку рибопромислової галузі держава повинна провести реструктуризацію податкової та митної політики, фінансування якої повинно проводитись за рахунок коштів державного 
бюджету. Також слід проводити фінансування організацій, що займаються вивченням, охороною та відтворенням рибних запасів, а також науково-дослідних організацій, які виконують тематичні роботи, що мають загальнодержавне значення. Як бачимо з досвіду зарубіжних держав, у 2014 році Свропейська Комісія затвердила ключовий інвестиційний пакет для галузі рибальства Латвіі та сектору аквакультури на суму майже 184 млн. євро, включаючи 139 млн. євро інвестицій ЄС [6].

Таким чином для ефективного функціонування рибопромислового комплексу слід провадити інвестування за наступними пунктами:

- підтримка розвитку галузі рибальства, яка б грунтувалася на принципах сталості навколишнього середовища, ефективності використання ресурсів, інновацій, конкурентоспроможності та науковості;

- сприяння розвитку галузі аквакультури, яка б грунтувалася на принципах сталості навколишнього середовища, ефективності використання ресурсів, інновацій, конкурентоспроможності та науковості;

- допомога розвитку сфери реалізації та переробки продукції.

Висновки і перспективи подальших досліджень. Отже, для виходу досліджуваного сектору економіки із кризи, забезпечення сталого розвитку галузі, зміцнення продовольчої незалежності країни, слід перш за все, вирішити питання, які стосуються еколого-економічних проблем розвитку рибогоспо- дарського комплексу, удосконалення господарського механізму управління рибною галуззю, активізації інноваційних та інвестиційних процесів, раціонального використання природних водних живих ресурсів.

Також слід приділити неабияку увагу науково-технічному забезпеченню та науковому супроводженню діяльності рибного господарства. Пріоритетними напрямами буде наукове обгрунтування обсягів сировинної бази та раціонального рибальства, охорона водних екосистем, технології переробки водних рибних ресурсів.

При цьому великою проблемою є фінансування досліджень, адже вони мають першочергове значення для виробництва і забезпечення населення рибною продукцією та, в свою чергу, гарантують продовольчу безпеку. Але на даний момент, коли Україна перебуває в глибокій кризі, держава не в змозі здійснювати фінансування галузі за рахунок коштів державного бюджету. Коли всі витрати зведені до мінімуму, стає питання залучення інвестицій. Тому для врятування галузі слід шукати нових партнерів. Також важливо здійснити співробітництво 3 країнами-партнерами у сфері спільного вивчення сировинних ресурсів, рибопереробки і маркетингу створення інфраструктури рибогосподарської галузі, підготовки фахівців тощо. Ці заходи необхідні для ліквідації «вузьких місць» рибної промисловості.

\section{Література}

1. Закон України «Про рибу, інші водні живі ресурси та харчову продукцію з них» від 06.02.2003. №486-IV зі змінами та доповненнями від 05.09.2013. Режим доступу: http//rada.gov.ua

2. Закон України «Про аквакультуру» від 08.09.2012. № 5293-VI. Режим доступу: http//rada.gov.ua

3. Закон України «Про рибне господарство, промислове рибальство та охорону водних біоресурсів» від 18.09.2012. № 3667-17. Режим доступу: http//rada.gov.ua

4. Вдовенко Н. М. Регуляторная политика государства и механизмы ее реализации в перспективных отраслях экономики, связаных с рыбным хозяйсвом / Н. М. Вдовенко // Економіка Розвитку. - Харків : ХНЕУ, 2014. - № 3 (71). - С. 10-14.

5. Борщевський П.П. Рибний ринок України: проблеми і перспективи розвитку / П. П. Борщевський, М. С. Стасишен // Економіка України. - 2010. - № 3. - С. 51-57.

6. Яркина Н. Н. Рыбное хозяйство Украины как часть мирового рыбохозяйственного комплекса: тенденции, проблемы, перспективы [Текст] / Н. Н. Яркина //Економічний часопис - XXI. - Київ, 2013. - № 3-4 (1). C. $75-78$.

7. Яркіна Н. М. Стратегія управління рибогосподарською діяльністю / Н. М. Яркіна // Економіка України. - Київ : Преса України, 2014. - № 2(627). - С. 63-70.

8. Офіційний сайт Державного комітету статистики України: http://ukrstat.gov.ua

9. Офіційний сайт Державного агентства рибного господарства країни: http://darg.gov.ua

10. Офіційний сайт Української рибопереробної компанії: http://ua-region.com.ua 


\author{
Самофратова В.A. \\ кандидат экономических наук, доцент \\ E-mail:vica_samofatova@mail.ru \\ Демчук С.И. \\ магистрант \\ кафедра экономики промышленности \\ Одесская национальная академия пищевых технологий \\ ул. Канатная, 112, г. Одесса, Украина, 65039 \\ E-mail: svetlana93@i.ua
}

\title{
СОВРЕМЕННОЕ СОСТОЯНИЕ И НАПРАВЛЕНИЯ РАЗВИТИЯ РЫБНОГО ХОЗЯЙСТВА ВО ВНУТРЕННИХ ВОДОЕМАХ УКРАИНЫ
}

Проанализированы тенденции развития рыбного хозяйства Украины, определены проблемные аспекты обеспечения населения Украины отечественной рыбой и продукцией ее переработки. В статье исследованы составляющие восстановления функционирования внутренних водоемов Украины, выделены основные проблемы и перспективы их решения в современных условиях.

Рыбное хозяйство - отрасль народного хозяйства, к которой принадлежат добыча, переработка, воспроизводство и увеличение запасов рыбы и других водных организмов в естественных и искусственных водоемах. Дает ценные пищевые, кормовые, лекарственные и технические продукты. Среди рек Украины основное рыбохозяйственное значение имеют Днепр (среди его притоков - главные Припять и Десна), нижний Дунай, меньше Днестр, Южный Буг и Северский Донец. Рыбное хозяйство Украины играет значительную роль в обеспечении населения продовольствием, а отраслей национальной экономики сырьем, а также в воссоздании природных ресурсов и повышении занятости населения. Также имеет существенное значение в организации рационального питания населения, поскольку рыбные продукты являются одним из источников белков и жиров животного происхождения.

Сейчас рыбное хозяйство переживает не лучшие времена из-за финансовых трудностей в государстве, а именно: нарушение хозяйственных связей, ухудшение экологического состояния внутренних водоемов, недостаточный объем работ по воспроизводству рыбных запасов. Таким образом, наблюдается значительное уменьшение объемов выращивания товарной рыбы, вылова рыбы во внутренних водоемах. Выделен ряд проблем, сдерживающих дальнейшее развитие рыбного хозяйства: состояние воспроизводства и охраны водных биоресурсов; восстановление функционирования имеющихся внутренних водоемов страны для их эфрфективного использования по назначению; государственное регулирование и поддержка отрасли.

Для выхода исследуемого сектора экономики из кризиса, обеспечения устойчивого развития отрасли, укрепления продовольственной независимости страны следует, прежде всего, решить вопросы, касающиеся эколого-экономических проблем развития рыбохозяйственного комплекса, совершенствования хозяйственного механизма управления рыбной отраслью, активизации инвестиционных процессов и инноваций, рационального использования природных водных живых ресурсов. Приоритетными направлениями будут: научное обоснование объемов сырьевой базы и рационального рыболовства, охрана водных экосистем, технологии переработки водных рыбных ресурсов, что положительно повлияет на продовольственную безопасность Украины.

Ключевые слова: рыбное хозяйство, пресноводные водоемы, инвестирование, инновационные технологии. 


\author{
Samofatova V.A. \\ $\mathrm{PhD}$, Associate Professor \\ Department of Industrial Economics \\ E-mail: vica_samofatova@mail.ru \\ Demchuk S.I. \\ Undergraduate \\ Department of Industrial Economics \\ Odessa National Academy of Food Technologies \\ Kanatna str., 112, Odessa, Ukraine, 65039 \\ E-mail: svetlana93@i.ua
}

\title{
THE CURRENT STATE AND DEVELOPMENT TRENDS OF FISHERIES IN INLAND WATERS OF UKRAINE
}

The trends of Fisheries of Ukraine, identified aspects of the problem of Ukraine's population of domestic fish and products of its processing. In the article the components of the recovery operation of inland water bodies of Ukraine, identified the main problems and prospects of their decision today.

Who fisheries going through hard times due to financial difficulties in the country, namely the violation of economic ties, the deterioration of the ecological status of inland waters, insufficient work on the reproduction of fish stocks. Thus, there is a significant decrease in the cultivation of marketable fish, fishing in inland waters. It highlighted a number of problems hindering the further development of fisheries: the state of the reproduction and protection of water resources; restoring the functioning of the existing inland water bodies of the country for their effective use; government regulation and support for the industry.

To exit the test sector out of the crisis, ensure sustainable development of the sector, strengthening food sovereignty of the country should first address issues relating to ecological and economic problems of development of fishery industry, improving the economic mechanism fisheries management, investment processes and innovation, sustainable use of natural aquatic resources. The priority areas are: scientific substantiation of the volume of raw material base and sustainable fisheries, protection of water ecosystems, water processing technology of fisheries that have a positive impact on the food security of Ukraine.

Keywords: fisheries, freshwater, investment, innovation technologies.

\section{References}

1. Zakon Ukrayini «Pro ribu, inshi vodni zhivi resursi ta harchovu produktsiyu z nih» vid 06.02.2003 №486-IV zi zminami ta dopovnennyami vid 05.09.2013. Rezhim dostupu: http//rada.gov.ua.

2. Zakon Ukrayini «Pro akvakulturu» vid 08.09.2012. № 5293-VI. Rezhim dostupu: http//rada.gov.ua.

3. Zakon Ukrayini «Pro ribne gospodarstvo, promislove ribalstvo ta ohoronu vodnih bioresursiv» vid 18.09.2012. № 3667-17 Rezhim dostupu: http//rada.gov.ua.

4. Vdovenko N.M. (2014). Regulyatornaya politika gosudarstva i mehanizmyi ee realizatsii v perspektivnyih otraslyah ekonomiki, svyazanyih s ryibnyim hozyaysvom. Ekonomika Rozvitku. HarkIv: HNEU, № 3(71), 10-14.

5. Borshchevskyi P.P., Stasyshen M.S. (2010). Rybnyi rynok Ukrainy: problemy i perspektyvy rozvytku. Ekonomika Ukrainy, № 3, 51-57.

6. Yarkyna N.N. (2013). Rybnoe khoziaistvo Ukrayny kak chast myrovoho rybokhoziaistvennoho kompleksa: tendentsyy, problemy, perspektyvy [Tekst]. Ekonomichnyi chasopys. KhKhI. Kyiv, № 3-4(1), 75-78.

7. Yarkina N.M. (2014). Stratehiia upravlinnia rybohospodarskoiu diialnistiu. Ekonomika Ukrainy. Kyiv: Presa Ukrainy, № 2(627), 63-70.

8. Ofitsiinyi sait Derzhavnoho komitetu statystyky Ukrainy: http://ukrstat.gov.ua.

9. Ofitsiinyi sait Derzhavnoho ahentstva rybnoho hospodarstva Ukrainy: http://darg.gov.ua.

10. Ofitsiinyi sait Ukrainskoi rybopererobnoi kompanii: http://ua-region.com.ua. 